\title{
遺伝子導入マウスと遺伝子欠損マウスが創られるまで
}

\section{村上 和雄}

一般に研究の成果光のものより，光の成果が生まれるプロ セスのほうが興味深く, 他の分野の研究者にとっても参考に なる場合が多い. 光のプロセスの中で, 暗中模索, 悪戦苦闘を 繰り返し, 時には不思議な出会いに導かれ, 研究が進展するこ とがしばしばある.ここでは,つくば高血圧マウスとつくば低 血圧マウスという新しいマウスが, 多くの研究者の協力によ り, 試行錯誤を繰り返しながら創作されたプロセスについて 紹介する。

最新の統計によると, 高血圧症と見なされている人は, 国内だけで 2 千万人を超える.さらに 21 世紀には，すべ ての国で，高血圧症などを危険因子とする循環器疾患が 最大の死因になると, 世界保健機構は推定している。長 年にわたり，この高血圧症の発症・継続に関して，膨大 な研究が積み重ねられてきた。 その病因は, 遺伝的背景 と環境因子（食塩の過剩摂取やストレスなど）の複雑な 相互作用の結果であると見なされているが，その詳細な
機構はほとんど不明である。

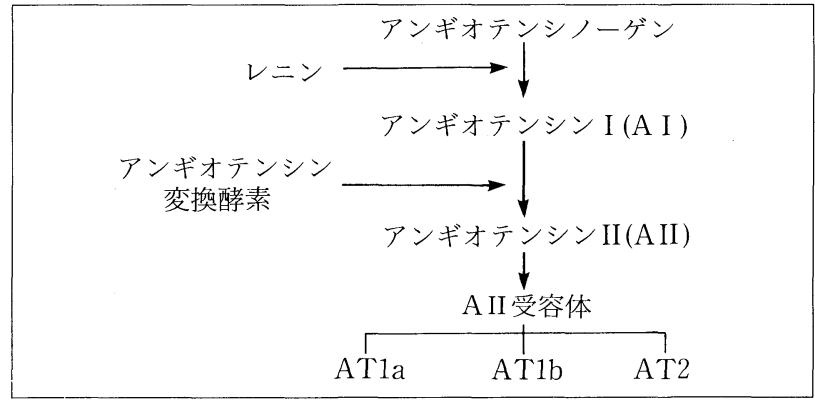

図 1 ロレニン・アンギオテンシン系の概略図

腎蔵で産生されたレニンは, 血中でその基質であるアンギオテンシ ノーゲンと出会い, デカペプチドのアンギオテンシン I（A I ）を つくる. A I には生理作用がないが, 変換酵素の作用によって A I から生じたアンギオテンシンII (A II) は, 現在知られている最も 強力な昇圧物質である. A II 受容体には 1 型と 2 型があり, 1 型に は $1 \mathrm{a}$ 型と $1 \mathrm{~b}$ 型がある. A II受容体のサブタイプを使い分けるこ とにより, A II は多彩な生理作用を営むものと推定されている. 


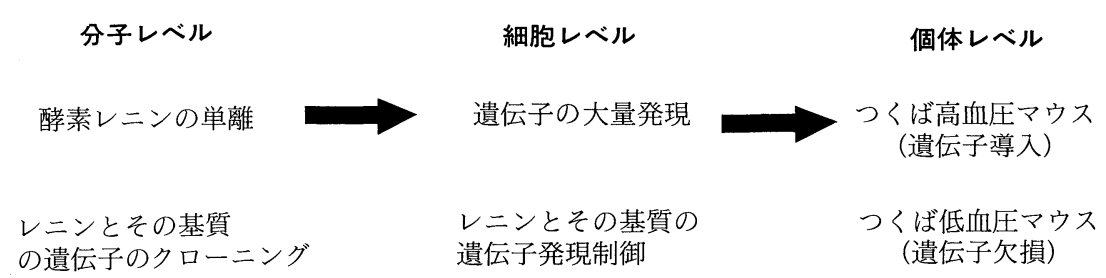

図 2 高血压マウスとつくば低血圧マウスの創作までのプロセス

この病因を明らかにするため，筆者らは，昇圧酵素で あるヒト・レニンとヒト・レニン基質（アンギオテンシ ノーゲン) の遺伝子をもち, 高血圧症状を呈する遺伝子 導入マウス (つくば高血圧マウス)を 1993 年に創作した。 また，レニン基質遺伝子を欠損させた低血圧マウス（つ くば低血圧マウス)も 1994 年に創作した. 図 1 に示すレ ニン・アンギオテンシン系は, 全高血圧症の $2 / 3$ 以上の 発症・継続に関与していることが, 最近の研究でわかっ てきている. 本稿では, 図 2 に示したように, 2 種類のマ ウスが，分子や細胞レベルの研究を経て，どのようにし て創作されたかを解説する。

\section{不思議な緑}

筆者は, 1969 年から 1976 年まで, アメリカ・テネシー 州のバンダービルト大学の稲上 正教授のもとで研究に 従事した.この大学で, 偶然の機会から, S. Cohen 教授 らとともにマウス顎下腺のレニンの単離をすることがで きたので, この成功をバネにして, 1972 年頃からレニン 研究の中心である腎レニンの単離に全力をあげた。しか し, この研究は, 多くの先人の失敗が示す通りそう簡単 ではなく, 筆者も悪戦苦闘してほぼ諦めかけていた。

ちょうどその頃, 幸いにもタンパク質や酵素の単離法 として, 新しい方法が登場しつつあった。その原理は簡 単で, 筆者は “抢とり”作戦と名づけていた。単離しよ うとするタンパク質（この場合レニン）と特別に親和性 のあるリガンドと呼ばれる “おとり物質”を探してきて, このリガンドを不活性な担体に結合させ，この担体を詰 めた容器（アフィニティー・カラム）を作ろうとした。

しかし, 当時この方法はまだ新しく, 筆者はくる日も くる日もリガンドを探し, その効果のテストに明け暮れ ていた. そして約半年後, 一つの新しいリガンドに出会 った.このリガンドは, 梅沢浜夫博士や青柳高明博士ら によって, 微生物から発見・単離され, 構造も決定して いた酸性プロテアーゼの阻害剤の 1 つでペプスタチンと
呼ばれるペプチドであった.このペプスタチンをリガン ドとするアフィニティー・カラムと, 従来の酵素の単離 法とを組み合わせ，腎臓からレニンを初めて純粋な形て 取り出すことができた。この時，レニンが発見されてか ら 70 年あまりが経っていた。筆者は, 約 20 年前, アメ リカの稲上研究室で，レニンの最終標品が純粋であるこ との証明を手にした時の感激を，今でも鮮明に記憶して いる.

この研究は, Cohen 教授(1986 年ノーベル医学生理学 賞受賞）との出会いや，日本で発見されたペプスタチン という新物質がなければ完成されていなかったと思う. 一つの研究が, 自分の才能や努力だけでなく,多くの人々 によって支えられ，また不思議な出会いによって進展す る一例である。この研究が突破口になり，レニンの生化 学的な研究は，急激な展開を見せるようになる，その一 つとして, 当時稲上研究室に留学中の的場輝佳博士(現 奈良女子大学), 横沢英良博士 (現 北海道大学薬学部) ら とともに，筆者はラットやヒトの腎臓からレニンを単離 した ${ }^{(1,2)}$.

\section{高血圧ラットとともにハイデルベルグへ}

帰国後しばらくして, 故岡本耕造博士を訪問し, 有名な 高血圧自然発症ラット (SHR) や脳卒中易発症ラット (SHRSP) を分与していただき，これらのラットのレニ ンの血中動態の研究を行なった。 また, 当時 SHRSP の 脳卒中の発症率が日本とドイッで異なることから，岡本 先生の依頼により, SHRSP を飛行機のシートの下に置 き，ラットのご機嫌を伺いながら，ハイデルベルグの Ganten 教授に届けに行ったこともあった。

この SHR やSHRSP が創作されたお陰で，高血圧症 や,それに伴う脳卒中の研究は素晴らしい成果をあげた。 しかし，これらのラットは自然交配を重ねて創作された もので, 高血圧の発症・継続のメカニズムと遺伝子の関 係は, 創作以来 30 年を経過した現在でも不明である。こ 
のSHR と SHRSP の研究にたずさわった経験が，後で 述べるつくば高血圧マウスの創作の背景になった。

一方, レニンの研究は, 腎臓だけでなく他の器官へと 発展しつつあった。

\section{ウシ 3 万 5 千頭作戦}

1981 年, 稲上研究室に留学していた広瀬茂久博士 (現 東京工業大学生命理工学部）らは, 脳の下垂体などにも レニンが存在する決定的な証拠をつかんだ。幸いにも， 広瀬博士が筑波大学の筆者らのグループに加わったのを 機会に, ウシ脳下垂体からのレニンの単離に挑戦した。 この研究で一番苦労したのは，できるだけ多くの脳下垂 体を集めることであった。

東京の食肉センターから運んできた脳下垂体の殼を一 つずつ取り除き, 前葉と後葉に分ける作業を, ほとんど 毎日朝早くから広瀬博士を中心に研究室総出で行なっ た. 約 7 力月後, 3 万 5 千頭のウシ脳下垂体前葉 (粉末で 約 $50 \mathrm{~kg}$ ) から,レニンの単離を行なった. 方法は, 以前, 腎臓から単離した方法と基本的には同じであるが，材料 が限られていたため, 幾度も予備実験を繰り返し, 最適 条件を決めた後, 一気に純化を行なった. 約 200 万倍と, 当時としては記録的な精製倍率であったが，単離できた 量は, わずかに $0.5 \mathrm{mg}$ であった ${ }^{(1,2)}$.この研究により, 脳にもレニンが存在することが証明でき, 脳下垂体のレ ニンと腎レニンとでは糖鎖が異なっていることを見いだ した。これらの研究は, 単調で根気のいる仕事であった.

このようにしてレニンは単離され, その性質の一部が 明らかになった。しかし, 純化された量はいずれもごく わずかであり,この量では, レニンの基本構造（アミノ 酸配列)を明らかにすることは不可能であった。ここで, 筆者らの研究は大きな壁にぶつかった。しかし, 今から 考えると，この実験の難しさが我々には幸いした。この レニンの単離の困難さが, 遺伝子工学の早期導入を促す ことになったのである.

\section{遺伝子エ学の導入}

1970 年代の後半にかけて登場した遺伝子工学は多く の人々の注目を集めつつあった. しかし当時は, 今と違 って遺伝子工学は技術的にも, いろいろな困難を抱えて いた，その中で，筆者らは次のような 3 つの目標を立て た.

(1) レニン遺伝子の暗号の解読とレニンの基本構造の 解明
(2) 組換え型ヒト・レニンの大量生産

(3) レニン遺伝子の調節機構の解明

最初の目標は, レニンの $\mathrm{cDNA}$ と核内遺伝子のクロー ニングであった。特にヒト・レニンは，その基質に対す る酵素化学的性質や免疫化学的性質が, 他の動物のレニ ンとは異なっていることから, cDNA と核内遺伝子構造 解析は重要な意味があった. また, 臨床的研究を行なう ためには, どうしてもヒト・レニンが必要であった。し かし, 最初からヒト・レニンでの cDNA のクローニング には，いろいろな理由で手が出なかった.

当時，マウス顎下腺レニンはレニンとしての生理的意 味はまったく不明であったが，大量に得られるため，よ く研究されていた。 その cDNAのクローニングは, 筆者 らを含む世界各地の 5 つのグループによりほぼ同時に始 められていたが, まず 1982 年にパスツール研究所のグル ープが完全な cDNA を得て, 全塩基配列とそれより推定 した全アミノ酸配列を発表した。 また，その発表と同時 に, 稲上グループが大量のマウス顎下腺レニンを調製し, タンパク質の側から全アミノ酸配列を決定した．当時, 筆者らもすでに約 700 塩基対からなるマウス顎下腺レニ ン cDNA を得ており，これが，ラット，ウシ，ヒトの核 内遺伝子と相補的に結合することを見いだしていたが， この cDNA は, 残念ながら完全長のものではなかった. 緒戦で, 筆者らはパスッール研究所に完敗したのである. しかし本命は, 生理作用が明確な腎レニン, 特にヒト・ レニンの cDNA のクローニングであった.そこで，この マウス顎下腺レニン cDNA をプローブとして，ヒト・レ ニン cDNA のクローニングにとりかかった。

\section{ヒト・レニン cDNAのクローニング}

ヒト・レニン cDNA のクローニングは，マウス顎下腺 レニンの場合に比べ, 格段に困難なものであった。理由 は, 正常なヒト腎臟のレニンやその mRNA 含量は, マウ ス顎下腺レニンの場合の約 $1 / 100$ 以下，全 mRNA のお よそ $0.01 \sim 0.001 \%$ 程度と推定されたからである. 目的 物の mRNA の含量が低いほどクローニングは困難で, この数字は当時の技術で cDNA クローニングが可能か 否かの限界であった. しかし, 幸い正常の約 10 倍ものレ ニン mRNA を含む試料を入手することができた.ここ から mRNA を抽出し, cDNA ライブラリーを作製した。

cDNA の合成には，1982 年に発表された OkayamaBerg 法を用い, 京都大学医学部の中西重忠教授のグルー プの協力もあり， cDNAの全塩基配列と全アミノ酸配列 を決定することができた。続いて，ヒト・レニンとヒト・ 
レニン基質の核内遺伝子のエキソン・イントロン構造を, その発現調節部位を含めて明らかにした ${ }^{(1,2)}$.

\section{個体レベルの研究}

これまで述べてきた分子や細胞の in vitro レベルで の研究は, 新技術の導入により目覚ましい進歩を遂げて きた。しかし，血圧が遺伝子によってどのように調節さ れているかについては, 分子や細胞レベルの研究は直接 には何も答えてくれない.しかし幸いにも，このような 限界を突破する発生工学という新しい技術が登場しつつ あった。筆者は, 実験動物中央研究所の野村達次所長を 訪ね，筆者らの実験計画を説明して，協力をお願いした。 野村所長は快く協力を約束して下さり, 当時, この研究 所で活躍中の勝木元也博士らとともに実験がスタートし た. 以下，この技術について簡単に解説しょう.

\section{1. 遺伝子導入 (トランスジェニック) マウスの作製（図} 3)

自然交配または過排卵処理によって得たマウス受精卵 の胚前核に，目的とする DNA 断片を顕微鏡下で注入す る.これを偽妊娠代理マウスの卵管に移植し，個体まで 発生させ, 得られた仔マウスの尻尾から DNA を抽出し, 目的遺伝子の導入を確認する。このマウスを用いて, 導 入遺伝子の発現機構や遺伝子産物の機能を個体レベルで 解析できる.

\section{2. 遺伝子欠損(ノックアウト)マウスの作製(図 4)}

すべての細胞に分化することが可能なマウス胚性幹細 胞 (embryonic stem cell ; ES 細胞) は, in vitro 継代 培養が可能である.そこでまず, 相同組換えにより ES 細 胞レベルで目的の遺伝子に変異を導入する. 変異が導入 された $\mathrm{ES}$ 細胞をスクリーニングし，この細胞を 8 細胞 期の宿主胚に注入し, 偽妊娠動物の子宮に移植し個体ま で発生させると, 体の各組織が ES 細胞および宿主細胞 由来の細胞からなるキメラマウスが得られる.これらの キメラマウスの中で, $\mathrm{ES}$ 細胞が生殖細胞へと分化した 個体を野生型マウスと交配させることにより，全体の細 胞で目的の遺伝子に変異が起こっている個体を作製でき る.

\section{ヒト・レニン遺伝子導入マウス}

筆者らの最初の試みは, ヒト・レニン遺伝子のマウス への導入である. 遺伝子本来の機能をトランスジェニッ

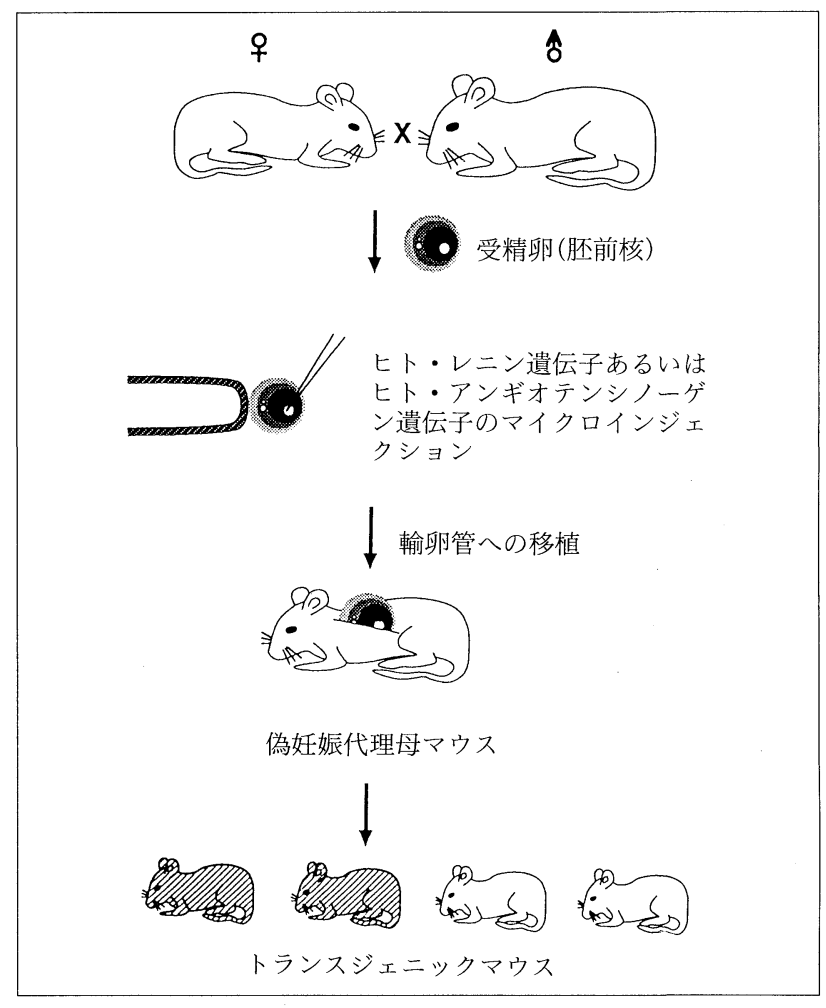

図 3 ・トランスジェニックマウスの作製法

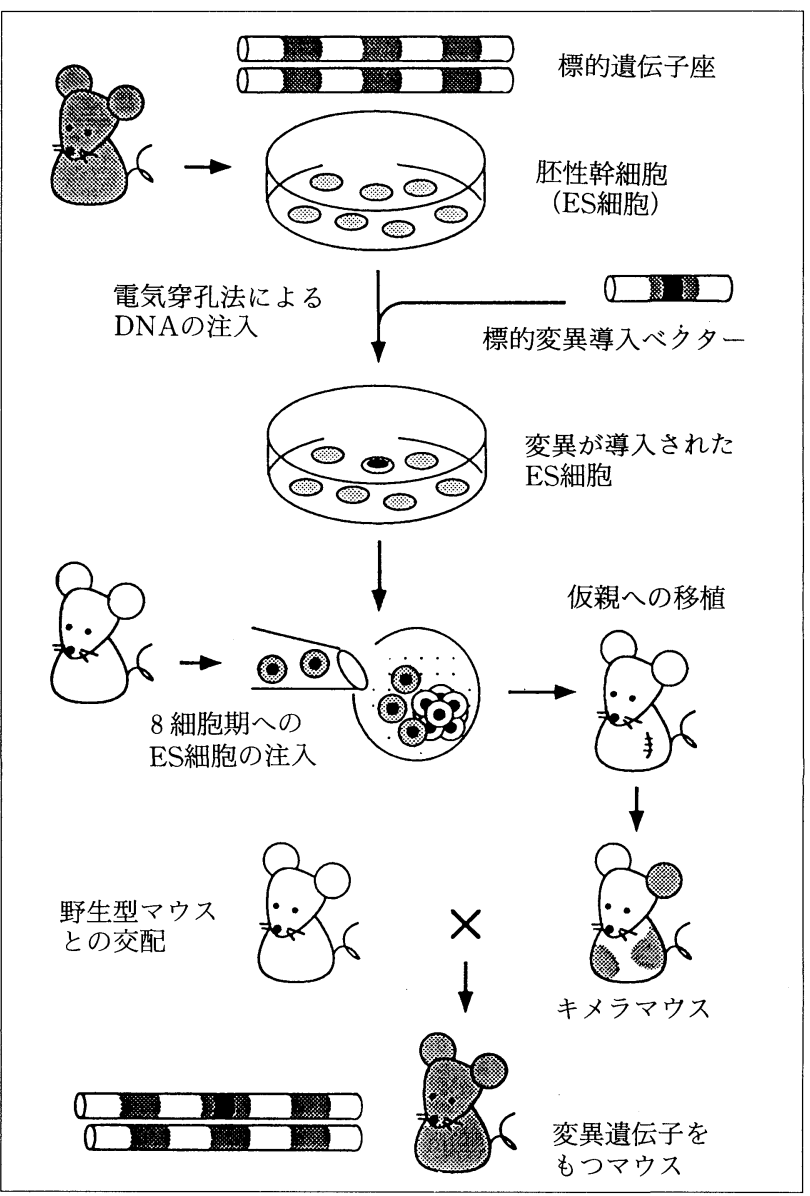

図 4 -遺伝子欠損マウス（ノックアウトマウス）の作製法 
ク個体においても正確に働かせるため，まず培養細胞を 用い，ヒト・レニン遺伝子の発現調節に関与するプロモ ーター領域を同定した.この結果に基づき, $3 \mathrm{~kb} の 5^{\prime}$ 上 流をプロモーター領域とした全長 $15 \mathrm{~kb}$ のヒト・レニン 遺伝子断片を調製し，この DNA を C57BL/6J 系統マウ スの受精卵に導入した。これらヒト・レニン遺伝子を有 するマウスは, メンデルの法則に従い次世代へ安定に伝 達された。また，マウス腎臓においては，ヒト・レニン 遺伝子が発現し, ヒト・レニンが産生されていることが 確認された。しかも，ヒト・レニンは予想通り，マウス 腎臓の傍系球体細胞のみに産生していた。ヒト・レニン 遺伝子導入マウスの腎藏におけるヒト・レニン量は, ヒ 卜の腎臟におけるそれと比較し 7.5 倍に増加していた が，これらマウスの血圧は野生型マウスの血圧と同様で あった。

\section{ヒト・アンギオテンシノーゲン遺伝子導入マウス}

筆者らの次の試みは, ヒト・アンギオテンシノーゲン 遺伝子のマウスへの導入である. そこで, ヒト・アンギ オテンシノーゲン遺伝子のプロモーター部位を細胞レベ ルで同定した。その結果に基づき, $1.3 \mathrm{~kb} の 5^{\prime}$ 上流領域 をプロモーター領域とした全長 $14 \mathrm{~kb}$ のヒト・アンギオ テンシノーゲン遺伝子断片を $\mathrm{C} 57 \mathrm{BL} / \mathrm{a} 6 \mathrm{~J}$ 系統マウスの 受精卵へ導入し, ヒト・アンギオテンシノーゲン遺伝子 を有するマウスを作製した。このマウスでも，次世代に 安定に外来遺伝子が伝達され, 100 コピー前後の外来遺 伝子が染色体の 1 個所に挿入されていた．このマウスの 肝臟において，ヒト・アンギオテンシノーゲンが強く発 現されていた。しかし，ヒト・レニン遺伝子導入マウス と同様に, このマウスにおいても, 血圧は野生型マウス と同じであった.

\section{つくば高血圧マウス ${ }^{(3,4)}$}

上記 2 種類のトランスジェニックマウスでは, 内在性 のレニン・アンギオテンシン（RA）系構成タンパク質が 存在するにもかかわらず，外来性のヒト RA 系の 1 つの 遺伝子の導入のみでは血圧が上昇しなかった。これは, 酵素レニンと基質アンギオテンシノーゲンの反応性に, 驚くべき厳密な種特異性が存在するためと考えられた。

そこで筆者らは, 次の試みとして, ヒト・レニン遺伝 子導入マウスとヒト・アンギオテンシノーゲン遺伝子導 入マウスとの交配により, 両外来遺伝子を保有するトラ ンスジェニックマウスの作出を行なった，その結果，両

\begin{tabular}{lc}
\hline & 収縮期血圧 $(\mathrm{mmHg})$ \\
\hline つくば高血圧マウス & $129.1 \pm 7.1$ \\
正常マウス & $100.4 \pm 4.4$ \\
つくば低血圧マウス & $66.9 \pm 4.1$ \\
\hline
\end{tabular}

遺伝子をもつトランスジェニックマウスは，通常の繁殖 方式にて得られ，このマウスの血漿中にヒト・レニンお よびヒト・アンギオテンシノーゲンが存在することが明 らかとなった。さらに，ヒト・レニンとヒト・アンギオ テンシノーゲン間の反応がマウス個体の血中で起こって いることは, 野生型マウスと比較し, 両遺伝子保有マウ スでは血漿アンギオテンシン I (A I ) 量が 3〜4 倍上昇 していることから，実証された。

また，両遺伝子保有マウスにおける A I の上昇は，同 様にアンギオテンシンII (A II) の上昇を導き, RA 系の 最終活性ペプチド（A II）が循環中に過剩に生成されて いることが明らかとなった（図 1)。そこで，血圧を非観 血式に測定した結果, 野生型マウス, ヒト・レニン遺伝 子導入マウス, 抢よびヒト・アンギオテンシノーゲン遺 伝子導入マウスでは，収縮期血圧は，いずれのマウスに おいても平均 $100 \mathrm{mmHg}$ と差がみられないのに対し, 両遺伝子を保有するトランスジェニックマウスでは，平 均 $130 \mathrm{mmHg}$ と有意に血圧の上昇が起こっていること が明らかとなり，このマウスを“つくば高血圧マウス” と命名した（表 1).

つくば高血圧マウスの血圧は，ヒト・レニンを特異的 に抑制する薬剤の投与により顕著に低下したが，野生型 マウスや，ヒトの 1 つの遺伝子のみを導入したマウスに おいては血圧の低下は認められなかった。これらの結果 より，つくば高血圧マウスにおいては，ヒト・レニンと ヒト・アンギオテンシノーゲンの特異的反応により産生 した過剰な A I が，内在性のマウス・アンギオテンシノ ーゲン変換酵素により A IIに変換され, 高血圧をひき起 こしていることが明らかとなった。

\section{つくば低血圧マウス ${ }^{(5)}$}

ES 細胞を用いた相同組換え法の可能性が Capecchi により考案され，遺伝子ターゲティングの技術により， ノックアウトマウスが誕生したのは，まだ数年前（1989 年)のことである.筆者らはまず, RA 系唯一の基質であ るアンギオテンシノーゲンの破壊を, この細胞を用いて 行なった. その結果, 野生型マウス抢よびへテロ変異型 マウス（アンギオテンシノーゲンの 2 つの遺伝子の内 1 つの遺伝子が欠損したマウス, 図 4)においては, アンギ 
オテンシノーゲン遺伝子発現が検出されたが, ホモ変異 型マウス（アンギオテンシノーゲンの 2 つ遺伝子とも 欠損したマウス）においては，同遺伝子の発現は検出さ れなかった。このことにより，個体レベルにおいて，ア ンギオテンシノーゲン遺伝子の半分または完全な欠損に 成功したことが示された。ささに，これらマウス血漿中 のアンギオテンシノーゲンおよび A I の産生は, ホモ変 異マウスにおいては検出限界以下であり，本動物がアン ギオテンシノーゲン欠損マウスであり， RA 系が機能し ないマウスであることが明らかとなった。そこで，この マウスの血圧を非観血式に測定したところ, 野生型マウ スとへテロ変異型マウスとの間には血圧に有意な差が観 察されなかった。これに対し, ホモ変異型マウスでは血 圧が，野生型マウスに比べて収縮期血圧で $34 \mathrm{mmHg} も$ 低く，このマウスを“つくば低血圧マウス”（表 1）と命 名した。これらのことから, 血圧維持において RA 系を 代償する昇圧系は存在せず，正常血圧制御においても RA 系が重要な役割を演じていることが明確に示され た.

\section{アンギオテンシン II 受容体遺伝子欠損マウス}

アンギオテンシンII（A II）受容体の精製およびその 遺伝子のクローニングは, 高血圧研究者の長年の夢であ ったが, 20 年以上にわたる多くの研究グループの試みに もかかわらず, 不可能であった.しかし, 1991 年から 1993 年にかけて, 以下に述べるょうに 1 型（AT 1) と 2 型 (AT 2) の 2 つの A II 受容体遺伝子 (図 1) のクローニン グやその細胞生化学的研究において, 稲上らは目覚まし い成果をあげた。

まず，動物培養細胞を用いた発現クローニングの方法 により, 受容体を精製することなく $1 \mathrm{a}$ 型受容体遺伝子 の cDNA のクローニングに成功し, その全塩基配列と全 アミノ酸配列が明らかにされた。

次いで 1992 年に, 内分泌腺に特異的な A II受容体 (1 $\mathrm{b}$ 型)をクローニングし, これが, 副腎, 脳下垂体などの 組織で特異的に発現していることを見いだした.この結 果, A IIが単に循環器系のみならず, 脳, 神経内分泌系 に関連している機構が明らかになった。

さらに 1993 年になって, 新しい A II 受容体遺伝子 (2 型）のクローニングに成功した。この受容体は, 脳, 胎 児, 心臓, 腎臓, 副腎などに発現しているが, 生理的意 義に関しては定説がなかった. 稲上らは, この 2 型受容 体が，1型受容体とは反対に細胞増殖を阻害する作用を もつことを見いだした。

\section{ブレーキとアクセル}

これまで述べたように，A II受容体には，少なくとも 2 つの型 $(1$ 型と 2 型)があり, 1 型には $1 \mathrm{a}$ と $1 \mathrm{~b}$ 型があ る(図 1). 従来知られていた A II の作用は，そのほとん どが 1 型を介して伝達されると推定されていた.この推 定を実証し，さらに $1 \mathrm{a}$ および $1 \mathrm{~b}$ 型の役割を明らかに するため, 筆者らは, 多くの臓器で発現している $1 \mathrm{a}$ 型の 遺伝子が欠損しているマウスを 1995 年に創作した ${ }^{(6)}$.こ のマウスの最高血圧は, 正常マウスに比べ, ヘテロ型で は $10 \mathrm{mmHg}$ ，ホモ型では $22 \mathrm{mmHg}$ それぞれ低下して いた。この結果は， RA 系による血圧のコントロールに は, $1 \mathrm{a}$ 型受容体が重要な役割を演じていることを示し ている.

ごく最近, 稲上らは 2 型受容体の生理的意義を解明す るため，この受容体遺伝子を欠損したマウスを作製する ことに成功した ${ }^{(7)} .2$ 型受容体は, 胎児の皮膚に多く発現 していることから，胎児発育などに重要な作用をもつ受 容体であると考えられていた。しかし，予想に反し，2型 受容体を欠損したマウスは, その血圧が顕著に上昇して おり $(25 \sim 30 \mathrm{mmHg})$ ，さらに静脈に注入した A II に対 して過敏な血圧上昇作用を示した。

したがって,この 2 型 A II受容体は, 主として血圧上 昇を抑える作用をもつことがわかった。つまり，A II は 血圧の調節に関して，まったく相反する作用を有するの である.すなわち，A IIは 1 型受容体（AT1）を経由し て血圧を上昇させる一方， 2 型受容体 (AT2) を経由して 血圧を降下させるという，大変興味ある事実が判明した のである.この事実は, A IIが血圧上昇という生理作用 に関して，アクセル ( 1 型受容体) とブレーキ ( 2 型受容 体）を巧みに使い分けていたことを示している.

この事実を知った時, 次のような京都大学満田研究室 でなされた発見を思い出した.すなわち,ビタミン $\mathrm{B}_{2}$ が FMN (フラビンモノヌクレオチド), さらに FAD (フラ ビンアデニンジヌクレオチド）と活性型になるのに ATP を必要とするが, この ATP のようなヌクレオチド および無機りン酸が, FAD と FMNの分解を司るホス ファターゼの強力なインヒビターとなるというまったく 予想外の事実が, 今から 30 年も前の 1965 年に発見され ていたのである(8).すなわち，ATP はFMN と FADの 合成を促進するとともに, それらの分解を抑えるという アクセルとブレーキの二役をやっていることになる，植 物内での ATP と, 動物におけるアンギオテンシンII受 容体が, それぞれ二役をこなしている点で同じだという, 自然界の精巧な仕組みに改めて驚いている. 


\section{将来の展望}

レニンとその遺伝子の単離から始まり，次いでそれら 遺伝子の細胞内での発現調節機構の研究を経て, 個体レ ベルにおける研究にたどり着いた。これらの結果を総合 して，レニン・アンギオテンシン（RA）系の主要な生理 作用は，心臟・血管系の血圧調節作用であることが害体 的に解明されたことになる. RA 系の研究は, 多くの人々 の努力により，一つのゴールに達したと思っている．し かし，このゴールは新しい研究の出発点でもある．なぜ なら，多彩な働きをすると推定されている RA 系の生理 作用については，まだまだ多くの謎が秘められているか らである。この謎を，これら新しいモデル動物を使って 解きたいと思っている.

まず，高血圧とそれに伴う，心臟，腎臓，脳などの臓 器障害発症の機構に, 組織の RA 系がどのように関与し ているかを解明したい。この目的のため，RA 系の遺伝 子導入 “ラット”も準備しており，このラットも間もな く誕生する予定である。ささらに，遺伝子の導入や欠損を

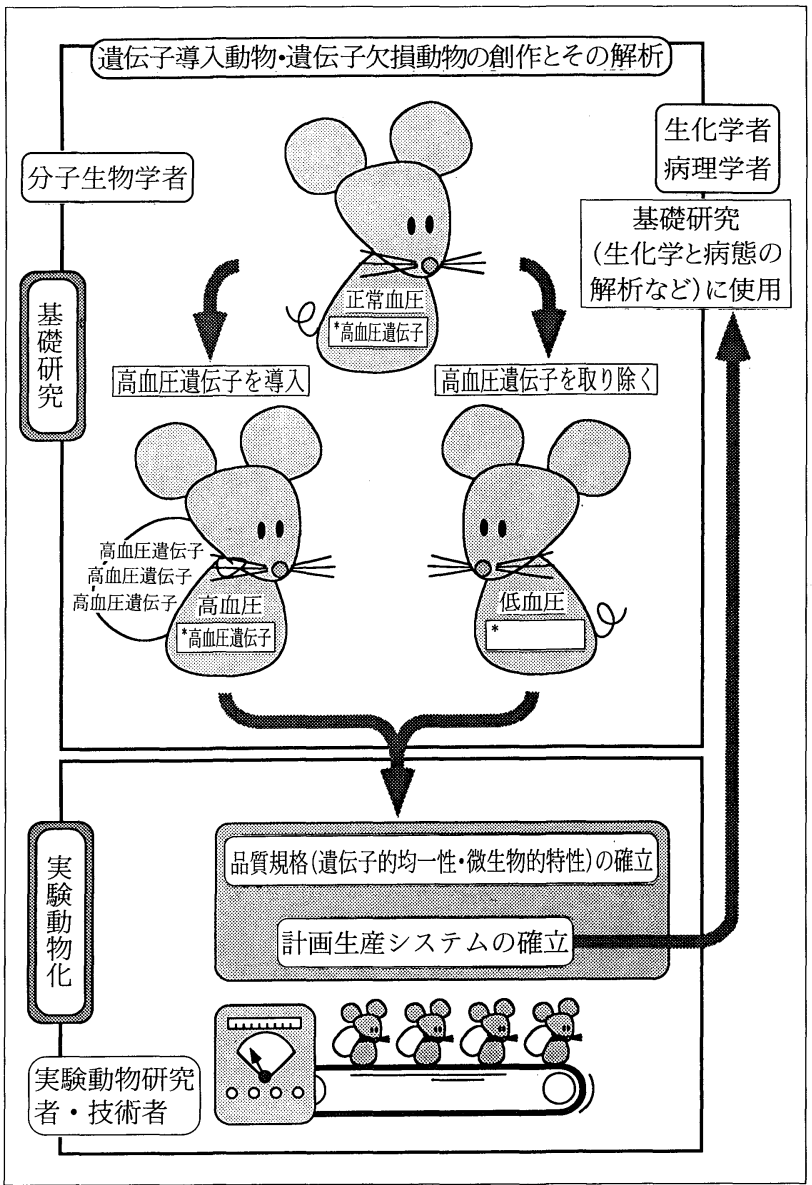

図 5 ・つくばマウス”研究の将来の展望

野村達次博士提供の図を一部変更したもの.
個体全体ではなく, 臓器や発生時期に特異的に行なって みたいと思っている. それにより, RA 系の研究で残され た最大の謎である, 組織における RA 系の真の生理作用 の解明が期待できるであろう.

そのためには，新しく創作された遺伝子導入動物や遺 伝子欠損動物の品質の規格を確立し, 計画生産システム を整備する必要がある（図 5)。この実験動物化は，実験 動物中央研究所との協力により，すでに始まっている. 実験動物研究者・技術者, 生化学者, 基礎および臨床の 医学者らが協力できる，世界規模の研究会を発足させた いとの夢を描いている。

謝辞 : 私の恩師であり, 今なおご指導を賜っている京都大学名誉教 授・満田久輝先生から, 基礎的な研究を徹底的にやることにより, それを応用研究に結びつけるという研究態度を教えていただきま した. 先生の教えの一部を, この研究で実施することができたよう に思います. 改めて, 先生のご指導に対して心より御礼申し上げま す. 次に，筆者のアメリカでの師である稲上正教授はじめ，本文で 名前をあげさせていただいた諸先生に対し,誌上を借りて感謝いた します。また，つくば高血圧マウスとつくば低血圧マウスの作製と その解析については，実験動物中央研究所長・野村達次博士はじめ 同研究所の多くの方々と, 筑波大学動物実験センター・八神健一博 士，杉山文博博士の協力なしでは不可能でした。これらの諸先生方 と，村上研究室の多くの共同研究者に対して御礼申し上げます。

\section{文献}

1）村上和雄：生化学，65(4), 260 (1993)；“高血圧の基礎から臨 床まで”，診断と治療社，1994，p. 12 .

2) K. Tamura, S. Umemura, A. Fukamizu, M. Ishii \& K. Murakami : Hypertension Res., 18(1), 7 (1995).

3) A. Fukamizu, K. Sugimura, E. Takimoto, F. Sugiyama, M.-S. Seo, S. Takahashi, T. Hatae, N. Kajiwara \& K. Murakami : J. Biol. Chem., 268, 11617 (1993).

4) K. Murakami \& A. Fukamizu : Proc. Jpn. Acad., 69(6), Ser.B, 129 (1993)

5) K. Tanimoto, F. Sugiyama, Y. Goto, J. Ishida, E. Takimoto, K. Yagami, A. Fukamizu \& K. Murakami : J. Biol. Chem., 269, 31334 (1994).

6) T. Sugaya, S. Nishimatsu, K. Tanimoto, K. Takimoto, E. Tanimoto, K. Imaizumi, Y. Hisada, A. Otsuka, H. Uchida, M. Sugiura, K. Fukuta, A. Fukamizu \& K. Murakami : J. Biol. Chem., 270, 18719 (1995).

7) T. Ichiki, P.A. Labosky, C. Shiota, S. Okuyama, Y. Imagawa, A. Fogo, F. Niimura, I. Ichikawa, B. Hogan \& T. Inagami : Nature, 377, 748 (1995).

8）満田久輝：学術月報，43(8), 22 (1990)；H. Mitsuda：Proc. Jpn. Acad., 42, 940 (1966). 